\title{
Genetics of naked grain oats in crosses with Brazilian genotypes
}

\author{
Cândida Braga Cabral, Sandra Cristina Kothe Milach, Luiz Carlos Federizzi, Cristhiane Abegg Bothona, \\ Ivone Taderka, Luis Marcelo Tisian and Emerson Limberger
}

\begin{abstract}
Six crosses between three naked oat (Avena sativa L.) germplasm sources from the USA and Australia and three Brazilian hulled genotypes were studied for the segregation of naked grain and multiflorous spikelet traits in the $\mathrm{F}_{2}$ and $\mathrm{F}_{3}$ generations. One major gene with incomplete dominance and expressivity for both traits was identified in all populations. The occurrence of intermediate types for naked grain varied with the population and did not depend on the germplasm source of naked grain used. The frequency of intermediate types varied among $\mathrm{F}_{2}$ populations indicating that selection for higher expressivity of naked grain could be used to develop Brazilian oat lines with naked grain.
\end{abstract}

\section{INTRODUCTION}

In southern Brazil, oat (Avena sativa L.) acreage has increased from about 10,000 ha to more than 400,000 ha in the past 10 years. The main reasons for the popularity of oats are its high nutritional value and its use as a cover crop (Federizzi et al., 1995). One of the drawbacks of using oats for feeding livestock is its thick fibrous hull, which lowers the energy value of the grain. Moreover, the low bulk density of the grain makes it more expensive to transport and store than other cereals. Naked oats eliminate these problems and have been used throughout the world for non-ruminant feeding (Valentine, 1995).

One major dominant gene in oat, $\mathrm{N}-1$, has been reported to be responsible for the naked grain trait (Simmons et al., 1978). In some crosses up to three (Moule, 1972) or four epistatic genes in oats (Jenkins and Hanson, 1976) were found to be involved in control of the trait. In all cases nakedness appears to be influenced by a major regulatory gene, the expression of which can be modified according to the genetic background within which it occurs (Valentine, 1995). Therefore, the expressivity of this trait has usually been reported to be incomplete and greatly influenced by the environment (Jenkins and Hanson, 1976).

The presence of multiflorous spikelets has been associated with naked grain and has been used as a morphological marker for selection of this trait (Marshall and Shaner, 1992). However, normal spikelets can sometimes have naked grain, so the correlation of the two traits is incomplete. There have been reports about the inheritance of naked oat (Marshall and Shaner, 1992). However, the number of genes present in the germplasm used in the present study and whether they relate to the $\mathrm{N}-1$ gene sources were not reported. We report the first study of naked grain segregation in crosses with Brazilian oat genotypes.
The objectives of the present study were to determine the inheritance of naked grain in crosses between three exotic sources of oat germplasm and Brazilian genotypes. We also wished to evaluate the association between multiflorous spikelets and naked grain, and to identify the best source of germplasm from which to develop naked grain oat varieties for Southern Brazil.

\section{MATERIAL AND METHODS}

Three naked grain oat genotypes from the USA and Australia and three hulled genotypes from Brazil were used in this study (Table I). Crosses were made between naked versus hulled grain classes in the greenhouse in 1994 resulting in six segregating $F_{2}$ populations (Table II). $F_{1}$ seeds were sown in June, 1995, in a screen house located in Eldorado do Sul, RS ( $30^{\circ} 05^{\prime} 52^{\prime \prime}$ south latitude, 51 ${ }^{\circ} 39^{\prime} 38^{\prime \prime}$ west longitude; elevation $46 \mathrm{~m}$ ), to obtain the $\mathrm{F}_{2}$ generation.

One hundred and fifty seeds of each $\mathrm{F}_{2}$ population and 20 seeds of each parental genotype were sown in the field in 1996 at the Agronomic Research Center of the Federal University of Rio Grande do Sul, located in Eldorado do Sul, $\mathrm{RS}$, in a completely randomized design. Each plant was an experimental unit. The plots were seeded at a rate of one seed per $0.15 \mathrm{~m}$ in rows spaced $0.3 \mathrm{~m}$ apart. The main panicle of each plant was harvested at maturity. Before threshing, each panicle was analyzed for the total number of spikelets and the number that was multiflorous. Individual panicles were further manually threshed and the total grain number and the number of naked grains were recorded.

Ten seeds of each $\mathrm{F}_{2}$ plant of three populations were planted (as above) in the field in 1997 at the Agronomic Research Center of the Federal University of Rio Grande do Sul using the same seeding rate as in 1996 (Table III). 
Table I - Oat genotypes used, their origin, genealogy and relevant traits.

\begin{tabular}{|lllll|}
\hline Genotypes & Origin & Genealogy & \multicolumn{2}{c|}{ Type of } \\
\cline { 3 - 5 } & & & Grain & Spikelets \\
\hline UFRGS8 & Brazil & Doral/3/Gemini/Cav2700/2/Sel.5872-1/X2682-1 & Hulled & Normal \\
UFRGS10 & Brazil & Cocker selection1217X//Cor/BCLA & Hulled & Normal \\
UFRGS881971 & Brazil & Unknown & Hulled & Normal \\
Paul & USA & CI9221/Hudson//RL3038/Dal/3/RPB120-73/ & Naked & Multiflorous \\
& & RL3038//Noble/4/O2998-22/5/O22557A6- & & \\
10894 & USA & 100-5/3/RL3038/Dal//Noble & & \\
OX881069 & Australia & Unknown & Naked & Multiflorous \\
\end{tabular}

Table II - Segregation of $\mathrm{F}_{2}$ plants for naked grain in six oat crosses.

\begin{tabular}{|c|c|c|c|c|}
\hline \multirow[t]{2}{*}{ Crosses } & \multicolumn{2}{|c|}{ Number of $F_{2}$ plants } & \multirow{2}{*}{$\begin{array}{c}\chi^{2} \\
(3: 1)\end{array}$} & \multirow[t]{2}{*}{ Probability } \\
\hline & Naked $^{a}$ & Hulled & & \\
\hline Paul x UFRGS881971 & 83 & 32 & 0.415 & 0.52 \\
\hline Paul x UFRGS8 & 74 & 34 & 2.42 & 0.12 \\
\hline Paul x UFRGS10 & 72 & 21 & 0.231 & 0.63 \\
\hline 10894 x UFRGS881971 & 65 & 23 & 0.450 & 0.50 \\
\hline 10894 x UFRGS10 & 62 & 26 & 0.333 & 0.56 \\
\hline OX881069 x UFRGS10 & 50 & 18 & 0.078 & 0.78 \\
\hline
\end{tabular}

aPlants that had at least one naked grain in the main panicle.

These populations were chosen because they were superior for important agronomic traits, having shorter plant height and earlier maturity than the others. At maturity the main panicle of each plant was harvested and analyzed for the total grain number and the number of naked grains as described for the $\mathrm{F}_{2}$ generation. $\mathrm{F}_{2: 3}$ families were kept separate for the analysis.

The frequency distribution for each $\mathrm{F}_{2}$ population was made for type of grain and spikelet using a class interval of about one fourth of the standard deviation of each population, according to Steel and Torrie (1980). Segregation ratios were tested for goodness-of-fit to predicted segrega- tion ratios with a chi-square test. The parent-offspring heritability was calculated for type of grain with the formula $\mathrm{h}^{2}$ $=$ covariance $\left(\mathrm{F}_{2} \mathrm{~F}_{3}\right) /\left(\operatorname{var} \mathrm{F}_{2} \cdot \operatorname{var} \mathrm{F}_{3}\right)^{1 / 2}$.

\section{RESULTS AND DISCUSSION}

A continuous distribution of $\mathrm{F}_{2}$ plants with a concentration of individuals in the extreme classes was observed in all crosses in terms of both the percentages of naked grain and multiflorous spikelets (Figure 1). Although there was usually a higher number of individuals that were $100 \%$ naked, for most crosses a significant number of individuals were also found that were in the intermediate classes (10 to $90 \%$ naked). The hypothesis of one dominant gene for naked grain was tested considering the hulled $(0 \%)$ versus the naked (10 to $100 \%$ ) class. A 3 naked: 1 hulled grain segregation was supported for all crosses (Table II). This indicates that there is a major gene segregating in all populations.

The broad range of the naked class, which varied from 10 to $100 \%$, was probably due to partial dominance associated with incomplete expression of the gene for naked grain. This hypothesis was supported by the observations of the behavior of the $F_{2: 3}$ families compared to their $F_{2}$ generation means (Table III). Although the genetic hypothesis of 1:2:1 was supported with data from the segregation of the $\mathrm{F}_{2: 3}$ families, a broad range of responses was observed

Table III - Segregation of $\mathrm{F}_{3}$ families and parent-offspring heritability $\left(\mathrm{h}^{2}\right)$ for naked grain in three oat crosses.

\begin{tabular}{|c|c|c|c|c|c|c|c|c|}
\hline \multirow[t]{2}{*}{ Crosses } & \multirow[t]{2}{*}{ Classes $^{\mathrm{a}}$} & \multirow{2}{*}{$\begin{array}{l}\text { No. of } F_{3} \\
\text { families }\end{array}$} & \multirow{2}{*}{$\begin{array}{c}\text { Average of } \\
\mathrm{F}_{2} \text { plants }\end{array}$} & \multicolumn{2}{|c|}{$\mathrm{F}_{3}$} & \multirow{2}{*}{$\begin{array}{c}\chi^{2} \\
(1: 2: 1)\end{array}$} & \multirow[t]{2}{*}{ Probability } & \multirow[t]{2}{*}{$\mathrm{h}^{2}$} \\
\hline & & & & Range $^{b}$ & Average & & & \\
\hline \multirow[t]{3}{*}{ Paul x UFRGS8 } & $\mathrm{N}$ & 22 & 0 & - & 0 & 0.64 & 0.72 & 90 \\
\hline & I & 45 & 78.2 & $1.22-98.5$ & 61.1 & - & - & - \\
\hline & $\mathrm{H}$ & 18 & 100 & - & 100 & - & - & - \\
\hline \multirow[t]{3}{*}{10894 x UFRGS881971 } & $\mathrm{N}$ & 18 & 0 & - & 0 & 5.27 & 0.07 & 88 \\
\hline & $\mathrm{I}$ & 54 & 60.1 & $0.66-96.8$ & 50.3 & - & - & - \\
\hline & $\mathrm{H}$ & 15 & 100 & - & 100 & - & - & - \\
\hline \multirow[t]{3}{*}{10894 x UFRGS10 } & $\mathrm{N}$ & 13 & 0 & - & 0 & 5.83 & 0.05 & 82 \\
\hline & $\mathrm{I}$ & 42 & 73.8 & $0.30-98.3$ & 52.1 & - & - & - \\
\hline & $\mathrm{H}$ & 10 & 100 & - & 100 & - & - & - \\
\hline
\end{tabular}

${ }^{a}$ Classes of $\mathrm{F}_{3}$ families, where $\mathrm{N}=$ naked, $\mathrm{I}=$ intermediate, $\mathrm{H}=$ hulled. ${ }^{\mathrm{b}}$ Range of $\mathrm{F}_{3}$ family means. 
for the intermediate classes, which for the UFRGS10 $\mathrm{x}$ 10894 cross varied from 0.3 to $98.3 \%$ of naked grain family means. Partial dominance alone could not account for this variation because we would expect three distinct classes. Moreover, some of the $\mathrm{F}_{2: 3}$ lines derived from $\mathrm{F}_{2}$ plants without naked grain segregated for this trait. This occurred at a higher frequency for the populations from crosses with the 10894 naked grain source. In the case of the cross $10894 \times$ UFRGS881971, 18 out of the $87 \mathrm{~F}_{2: 3}$ lines were $0 \%$ naked, based on the average of all plants of each line (Table III), while 23 out of $88 \mathrm{~F}_{2}$ plants were $0 \%$ naked (the difference from 87 to 88 was due to loss of one line because of germination problems in 1997). Therefore, five $\mathrm{F}_{2}$ plants that were $0 \%$ naked originated more than one $\mathrm{F}_{3}$ plant that had some naked grains. Apparently there are other genes with smaller effects that are segregating not only in these, but probably in all populations. It is also possible that the environment influenced the expression of the naked grain in these populations. Even though the parental Brazilian genotypes had $100 \%$ hulled grain, the grain taken from the bottom of the panicle of the naked parents did not always thresh as expected.
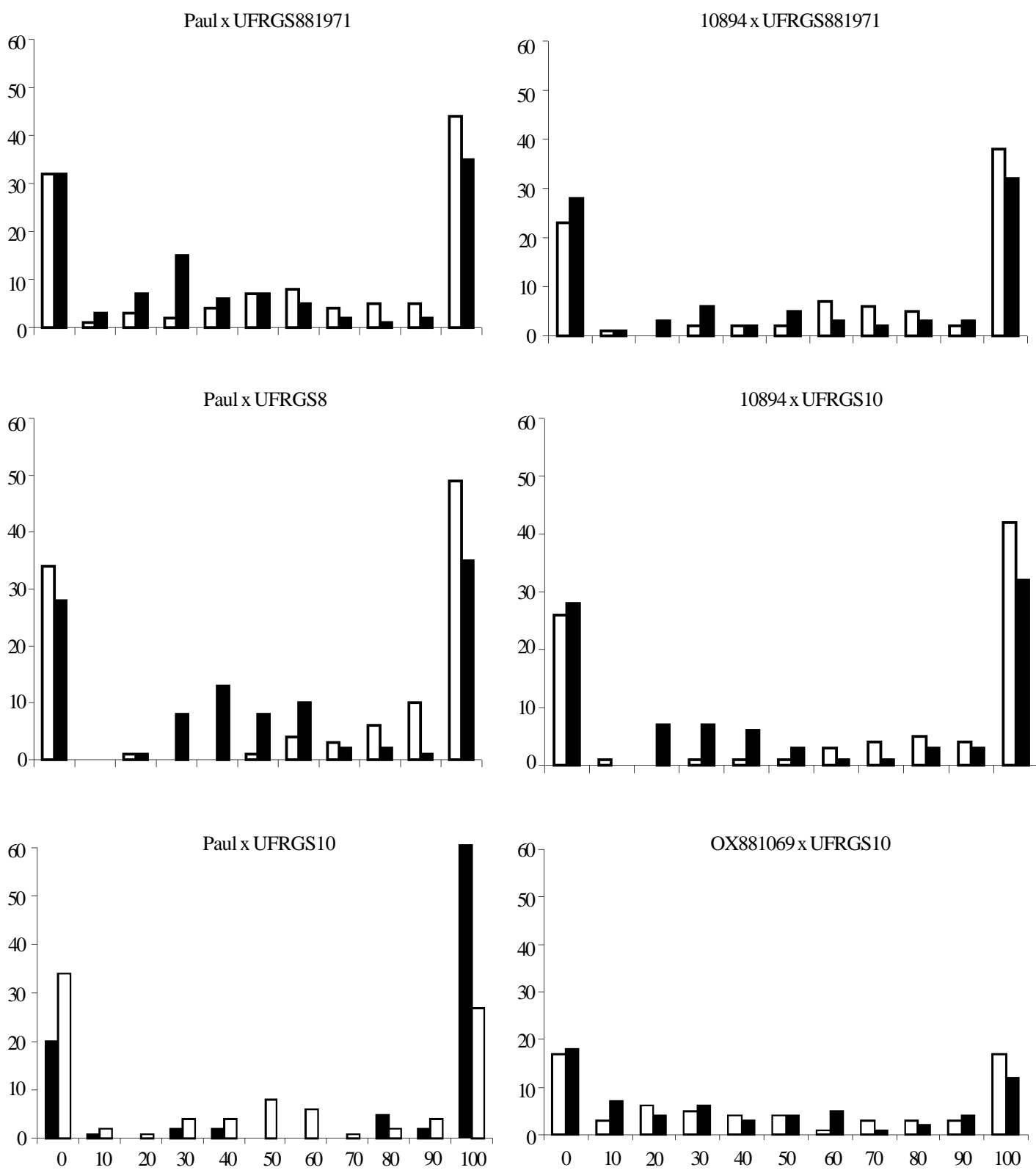

$\%$ of naked grain $(\square)$ and multiflorous spikelets

Figure 1 - Frequency distribution of $\mathrm{F}_{2}$ oat plants for grain (open bars) and spikelet (closed bars) types in six crosses between three naked (Paul, OX881069 and 10894) and three hulled (UFRGS8, UFRGS10 and UFRGS881971) genotypes. 
Table IV - Segregation of $\mathrm{F}_{2}$ plants for spikelet type

and correlation between multiflorous spikelets and naked grain in six oat crosses.

\begin{tabular}{|lcccccc|}
\hline \multirow{2}{*}{ Crosses } & \multicolumn{2}{c}{ Number of $\mathrm{F}_{2}$ plants $^{\mathrm{a}}$} & & $\begin{array}{c}\chi^{2} \\
(3: 1)\end{array}$ & Probability & $\mathrm{r}$ \\
\cline { 2 - 3 } & \multicolumn{2}{c}{ Multiflorous } & Normal & & & \\
\hline 10894 x UFRGS881971 & 67 & 28 & 1.01 & 0.31 & $0.83^{*}$ \\
Paul X UFRGS881971 & 83 & 32 & 0.49 & 0.48 & $0.88^{*}$ \\
10894x UFRGS10 & 63 & 28 & 1.62 & 0.21 & $0.75^{*}$ \\
Paul x UFRGS8 & 81 & 28 & & 0.05 & 0.82 & $0.67^{*}$ \\
OX88069 X UFRGS10 & 50 & 19 & & 0.22 & 0.64 & $0.85^{*}$ \\
Paul x UFRGS10 & 59 & 35 & 7.50 & 0.01 & $0.58^{*}$ \\
\hline
\end{tabular}

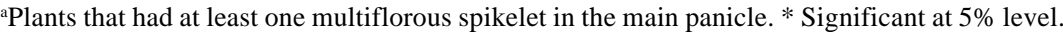

Our results are in agreement with those of Moule (1972), who identified one incomplete dominant gene modified by secondary genes for naked grain. However, contrary to the findings of Moule (1972), we suggest that these modifier genes may act independently of the major gene. We speculate that these modifier genes may influence the degree of lemma lignification. Consequently, even hulled genotypes with less lignified lemma may thresh quite easily.

The parent-offspring heritability was high for all crosses but was not $100 \%$, as would be expected for cases of partial dominance with incomplete expression (Table III). Heritability values were smaller for the two populations involving crosses with the 10894 naked grain source, reflecting the broader range of $\mathrm{F}_{2: 3}$ family means observed for these populations (Table III).

The segregation observed for the multiflorous spikelet trait was similar to the one described for naked grain (Table IV, Figure 1), confirming what would be expected for two pleotropically inherited characters (Jenkins and Hanson, 1976). However, the correlation between naked grain and multiflorous spikelet varied from 0.58 to 0.88 (Table IV). The correlation was not equal to one because inside the panicle normal spikelets with naked grain were common. On the other hand, panicles that had naked grain also had at least one multiflorous spikelet, indicating that the presence of this type of spikelet may be an easy way to select for plants with the major gene for naked grain. However, selection for a higher degree of naked grain expression should be direct and not through the expression of multiflorous spikelets.

Apparently the higher frequency of intermediate types for naked grain is not a consequence of the source of the germplasm (Figure 1), rather it depends on both the naked and the hulled genotypes involved in the cross. Thus, the Paul x UFRGS10 population (Figure 1) would be one of the easiest to select for in the $\mathrm{F}_{2}$ generation because it had the lowest frequency of intermediate types for naked grain. Whether the germplasm sources used in this study all have the same or different genes for naked grain remains to be determined through the analysis of segregating populations from crosses among them.

Although naked grain seems to be an easy trait to transfer to oat Brazilian germplasm, high selection pressure for expressivity should be used in order to develop lines that may be competitive as varieties. Using this strategy we have been able to select advanced oat lines, which we are entering in advanced trials. These lines have the potential to become the first legitimate Brazilian naked grain oat varieties.

\section{ACKNOWLEDGMENTS}

The authors greatly thank CNPq and FAPERGS for the financial support that made this study possible and Marcelo Teixeira Pacheco for technical assistance.

\section{RESUMO}

A herança dos caracteres grão sem casca aderida à cariopse e espiguetas multifloras foi estudada através da análise das gerações $\mathrm{F}_{2}$ e $\mathrm{F}_{3}$ de seis cruzamentos entre três fontes de germoplasma nuda dos EUA e Austrália e três genótipos brasileiros com grão com casca. Um gene com dominância e expressividade incompletas foi identificado em todas as populações para ambos os caracteres. A freqüência de plantas $F_{2}$ com expressão intermediária para o caráter grãos nudos variou de uma população para outra e não dependeu apenas da fonte de nuda utilizada. Seleção para maior expressividade do caráter grãos nudos deve ser feita para o desenvolvimento de linhagens brasileiras com grão não aderido à cariopse.

\section{REFERENCES}

Federizzi, L.C., Acauan, L.R., Carvalho, F.I.F. and Zanettini, M.H.B. (1995). Variabilidade fenotípica de diferentes caracteres da panícula em aveia (Avena sativa L.). Pesqui. Agropecu. Bras. 30: 223-229.

Jenkins, G. and Hanson, P.R. (1976). The genetics of naked oats (Avena nuda L.). Euphytica 25: 167-174.

Marshall, H.G. and Shaner, G.E. (1992). Genetics and inheritance in oat. In: Oat Science and Tecnology (Marshall, H.G. and Sorrels, M.E., eds.). Crop Science Soc. America. Inc. Publishers, Wisconsin, pp. 510-571.

Moule, C. (1972). Contribution a l'étude de l'hérédité du caractère 'grain nu'chez l'avoine cultivée. Ann. Amelior. Plant 22: 335-361.

Simons, M.D., Martens, J.W. and McKenzie, R.I.H. (1978). Oats: a standardized system of nomenclature for genes governing characters. US Dep. Agric. Agric. Handb. 509: 40.

Steel, R.G.D. and Torrie, J.H. (1980). Principles and Procedures of Statistics. McGraw-Hill, Inc., New York.

Valentine, J. (1995). Naked oats. In: The Oat Crop: Prodution and Utilization (Welch, R.W., ed.). Chapman \& Hall, England, pp. 504-532. 